\title{
Contributions to the smut fungi of Africa. 6. New records of Tilletia oplismeni-cristati, T. vittata, and T. perotidis
}

\section{Teodor T. Denchev* \& Cvetomir M. Denchev}

Institute of Biodiversity and Ecosystem Research, Bulgarian Academy of Sciences, 2 Gagarin St., 1113 Sofia, Bulgaria

Received 8 April 2020 / Accepted 17 April 2020 / Published 29 April 2020

Denchev, T.T. \& Denchev, C.M. 2020. Contributions to the smut fungi of Africa. 6. New records of Tilletia oplismeni-cristati, T. vittata, and T. perotidis. - Mycobiota 10: 1-11. doi: 10.12664/mycobiota.2020.10.01

Abstract. Additional records to three Tilletia species are reported from Africa: $T$. oplismeni-cristati on Acroceras calcicola from Madagascar, T. vittata on Oplismenus burmannii from Senegal, and T. perotidis on Perotis patens from Madagascar. Acroceras calcicola is a new host association for T. oplismeni-cristati, currently known only on species of Oplismenus. Descriptions, illustrations, and taxonomic notes are provided for these taxa.

Key words: Acroceras calcicola, Africa, grasses, Madagascar, Oplismenus burmannii, Perotis patens, Poaceae, Senegal, smut fungi, taxonomy, Tilletia oplismeni-cristati, Tilletia perotidis, Tilletia vittata

\section{Introduction}

Tilletia is a large genus of smut fungi (Ustilaginomycotina) comprising 189 species on grasses (Poaceae) (Bao et al. 2010; Vánky 2011, 2013; Denchev \& Denchev 2013; Li et al. 2014; Denchev, T. \& Denchev 2018a, b; Denchev et al. 2018). Most commonly, their sori are produced in the ovaries, which fill with a semi-agglutinated or powdery spore mass intermixed with sterile cells. In some species, the sori are formed in leaves and culms, as streaks. Exceptionally, the sori appear as swellings on the culms or cover the surface of the leaves, or form witches' brooms (Vánky 2013; Denchev, T. \& Denchev 2018a).

For many of the currently recognized species in Tilletia, only one to few specimens exist. This is mostly due to the cryptic nature of most members of this genus and to the fact that its highest diversity occurs in the tropical and subtropical regions of the world

\footnotetext{
${ }^{*}$ Corresponding author: e-mail: ttdenchev@gmail.com
} 
where very few collection trips for smut fungi have been carried out and where many species of this genus are yet to be discovered. The inadequate amount of Tilletia collections hinders the assessment of the species diversity, distribution, and host spectrum. Therefore, accumulation of data for poorly known species from understudied regions of the world, like Africa, is of high interest.

\section{Material and methods}

Dried specimens from the herbaria of the Meise Botanic Garden, Belgium (BR; herbarium codes according to Thiers 2020+) and National Museum of Natural History, Paris (P) were examined under a light microscope (LM) and scanning electron microscope (SEM). For LM observations and measurements, spores and sterile cells were mounted in lactoglycerol solution ( $\mathrm{w}: \mathrm{la}: \mathrm{gl}=1: 1: 2$ ) on glass slides, gently heated to boiling point to rehydrate the spores and sterile cells, and then cooled. The measurements of spores are given as min$\max$ (extreme values) (mean \pm 1 standard deviation). For SEM, spores and sterile cells were attached to specimen holders by double-sided adhesive tape and coated with gold in an ion sputter. The surface structure of spores and sterile cells was observed and photographed at $10 \mathrm{kV}$ accelerating voltage using JEOL JSM-7100F LV (for Tilletia vittata) and Hitachi SU3500 (for T. oplismeni-cristati and T. perotidis) scanning electron microscopes. The descriptions below are based entirely on the specimens examined. The shapes of spores and sterile cells are arranged in descending order of frequency.

\section{Taxonomy}

Tilletia oplismeni-cristati Vánky, Mycotaxon 89: 62, 2004. - Holotype on Oplismenus burmannii (Retz.) P. Beauv., Mexico, Sinaloa, ca $1 \mathrm{~km}$ E of Hotel Villa Blanca, La Capilla del Taxte, off Hwy. no. 40, 24 Oct 1976, leg. R. Durán \& P.M. Gray, s.n. (H.U.V. 14046; isotype WSP 68372). Paratype: ibidem, 1280 m, 10 Oct 1978, leg. R. Durán \& P.M. Gray, s.n. (H.U.V. 14047; isoparatype WSP 68614).

[Tilletia oplismeni-cristati Pat. \& Har., in sched. (nom. inval.)].

[Tilletia oplismeni-cristati Pat. \& Har. ex Durán \& G.W. Fisch., The genus Tilletia: 87, 1961

(nom. inval., Art. 40.1, Shenzhen Code)]. — On Oplismenus burmannii, Guatemala, Costa Rica, and Guadeloupe.

Sori in ovaries of some spikelets of infected plant, exceeding glumes, elongated, curved on top, ca $2.5 \times 0.8 \mathrm{~mm}$, covered by a thick, grayish brown, hispid pericarp that later ruptures exposing a powdery, blackish brown mass of spores and sterile cells. Sterile cells irregular, broadly ellipsoidal, subglobose or reniform, $(6-) 7-20(-23) \times(5.5-) 6.5-17(-20.5)$ $\mu \mathrm{m}$, often attached to spores, usually light yellowish brown, sometimes subhyaline; cell wall usually with two, thin layers (sometimes hard for observation), 1.0-1.5(-1.7) $\mu \mathrm{m}$ thick, occasionally with papilla. In SEM on the free surface rugulose to minutely verruculose, sometimes wrinkled, on the contact surface foveolate, with patterns corresponding to the ornaments of the spore to which the sterile cell was attached. Spores globose, subglobose, sometimes broadly ellipsoidal, (17.5-)18-21.5(-22) $\times(17-) 17.5-21(-21.5)(20.1 \pm 0.8 \times$ 

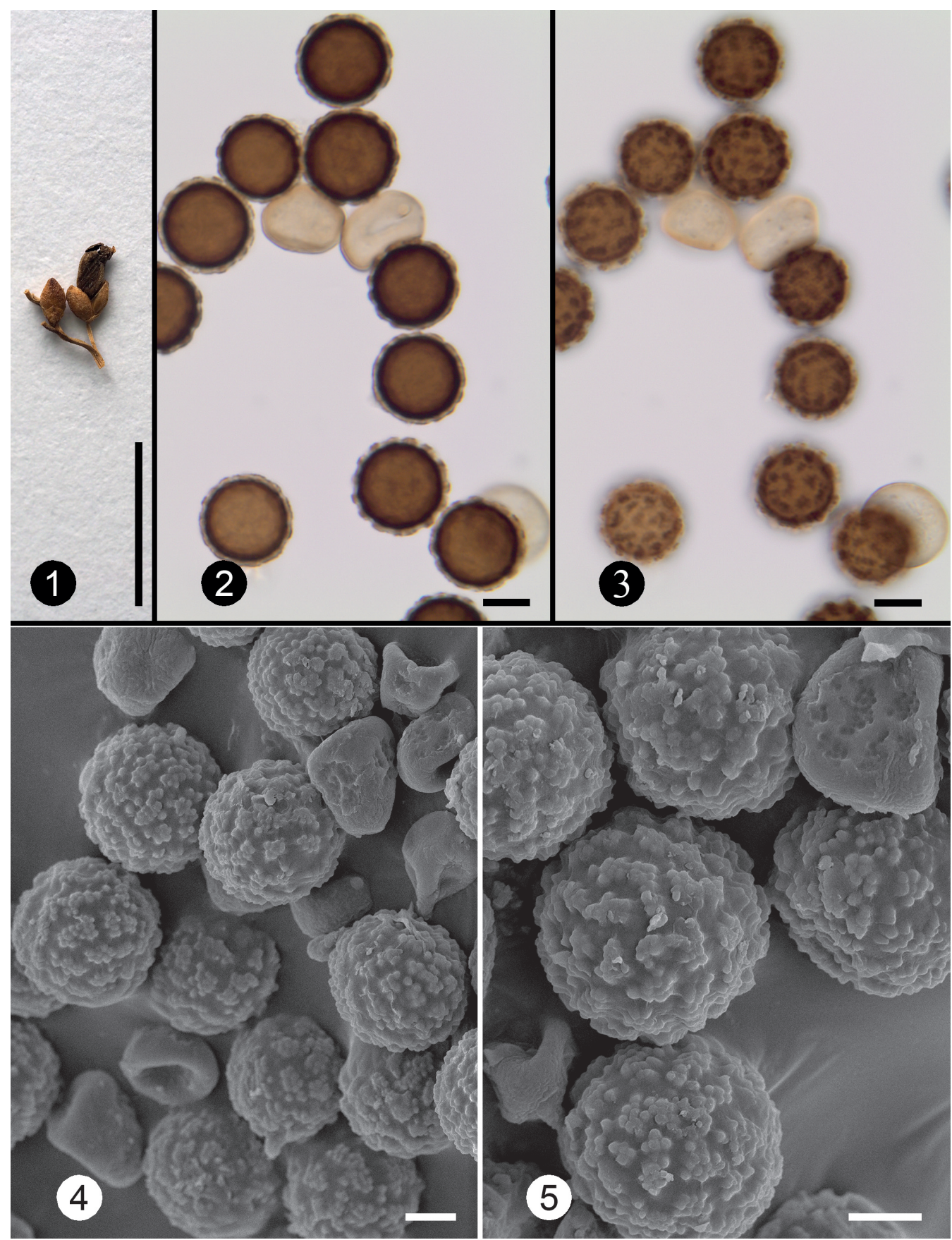

Figs 1-5. Tilletia oplismeni-cristati on Acroceras calcicola (P-P02329448). 1. Habit. 2, 3. Spores and sterile cells in LM (in median and surface view, respectively). 4, 5. Spores and sterile cells in SEM. Scale bars: $1=0.5 \mathrm{~cm}, 2,3=10 \mu \mathrm{m}, 4,5=5 \mu \mathrm{m}$ 


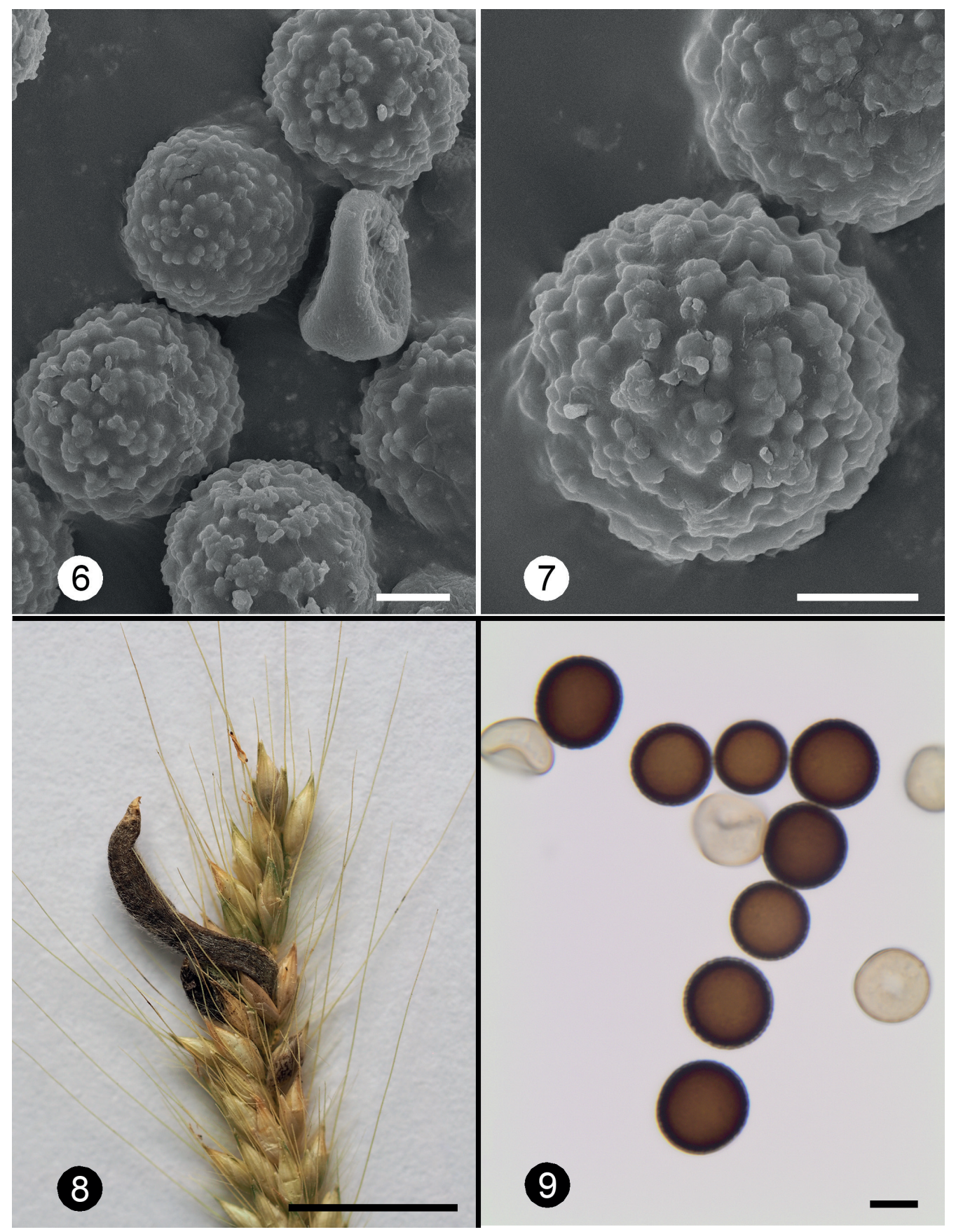

Figs 6, 7. Tilletia oplismeni-cristati on Acroceras calcicola (P-P02329448) - spores and sterile cells in SEM. Figs 8, 9. Tilletia vittata on Oplismenus burmannii (BR 0000015694461). 8. Habit. 9. Spores and sterile cells in LM (in median view). Scale bars: $6,7=5 \mu \mathrm{m}, 8=$ $0.5 \mathrm{~cm}, 9=10 \mu \mathrm{m}$ 
$19.7 \pm 0.8) \mu \mathrm{m}(\mathrm{n}=100)$, dark reddish brown; spore wall $(3.2-) 3.4-4.3(-4.6) \mu \mathrm{m}$ thick (including ornaments), two-layered (inner layer $0.6-1.1 \mu \mathrm{m}$ thick), with warts aggregated in clusters; clusters (12-)13-16(-17) on equatorial circumference, in optical median view with a flattened tip, (0.6-)0.8-1.6(-2.0) $\mu \mathrm{m}$ high, in surface view appearing as irregular, darker areas; hyaline sheath not seen. In SEM, spore wall with warts aggregated in clusters, sometimes solitary; clusters consist of up to $15(-20)$ warts, clusters sometimes connected by low, fine ribs.

Specimen examined - On Acroceras calcicola A. Camus: MADAGASCAR, ANOSY REGION, N of Behara, Ambatomika Airfield ('terrain d'aviation d'Ambatomika'), April 1960, leg. J. Bosser, no. 14624 (P-P02329448).

Distribution - On Poaceae: Acroceras calcicola, Oplismenus burmannii, and Oplismenus sp.; North America (Mexico), Central America (Guatemala, Costa Rica, and Guadeloupe), and Africa (Malawi and Madagascar).

Tilletia oplismeni-cristati is known to infect Oplismenus burmannii in North and Central America (Durán \& Fischer 1961; Durán 1987; Piepenbring 2003; Vánky 2004, 2011) and Oplismenus sp. in Malawi (Vánky 2004; Vánky et al. 2011). This smut fungus is reported here for the first time from Madagascar, on a new host plant, Acroceras calcicola.

Oplismenus and Acroceras (Poaceae: Panicoideae) are small genera (7 and 13 species, respectively) in the tribe Paniceae, subtribe Boivinellinae (Soreng et al. 2017). The morphological characters of the smut fungus on Acroceras calcicola, especially the spore wall ornamentation, match well that of T. oplismeni-cristati (comp. Durán 1987; Piepenbring 2003; Vánky 2004). No recent collections are available to confirm by molecular data the conspecificity of the fungus on Oplismenus burmannii and Acroceras calcicola.

The immature spores of Tilletia oplismeni-cristati have light yellowish brown colour, similar to that of the sterile cells. The two-layered spore wall can be observed much easily in the light-coloured, immature spores. Occasionally, the wall of sterile cells appears laminated with up to four thin, faint, and hard for observation layers. Rarely, some spores can have a short papilla.

The spore wall ornamentation of T. oplismeni-cristati, composed of warts aggregated in clusters, is unique in the genus Tilletia and is the best morphological feature by which this species can be identified or differentiated from T. imbecillis Vánky and T. vittata (Berk.) Mundk., which also infect hosts in Oplismenus (Vánky 2004, 2011). Another species of Tilletia, T. acroceratis Vánky, is also known on Acroceras from Africa (Vánky 2011; Vánky et al. 2011), but $T$. acroceratis differs by its larger spores (up to $25 \mu \mathrm{m}$ long) and the type of spore wall ornamentation (dense, polyangular projections with flattened top) (Vánky 2011).

Tilletia vittata (Berk.) Mundk., Trans. Brit. Mycol. Soc. 24: 312, 1941('1940'). EUstilago vittata Berk., Gard. Chron. 1853: 148, 1853. $\equiv$ Neovossia vittata (Berk.) H.S. Shetty \& Safeeulla, Indian Phytopathol. 33: 399, 1981('1980'). — Holotype on 'Oplismenoid grass' (Oplismenus compositus (L.) P. Beauv., det. C.E. Hubbard), India, Bihar, near the summit of Parasnath, alt. ca $1200 \mathrm{~m}$, before 1854, leg. W.J. Hooker, s.n. (K(M)).

Figs 8-13 




Figs 10-13. Tilletia vittata on Oplismenus burmannii (BR 0000015694461). 10. Spores and sterile cells in LM (in surface view). 11-13. Spores and sterile cells in SEM. Scale bars: $10=10 \mu \mathrm{m}, 11-13=5 \mu \mathrm{m}$ 
Sori in ovaries of some spikelets of infected plant, exceeding glumes, lemon-shaped to cylindrical, often curved, $2.5-10 \times 0.8-1.2 \mathrm{~mm}$, with a short, acute tip, bearing rudimentary style and stigmas, covered by a thin, brown, and hispid pericarp with parallel veins. The powdery, blackish brown mass of spores and sterile cells become evident upon rupturing of the pericarp. Sterile cells variable is size, irregular, broadly ellipsoidal, subglobose or reniform, (9.5-)10.5-18.5(-21) x (9-)10-16.5(-19.5) $(14.9 \pm 2.6 \times 13.4 \pm 2.1) \mu \mathrm{m}(\mathrm{n}=$ $50)$, light yellowish brown; cell wall usually two-layered (sometimes hard for observation), 0.7-1.7(-2.0) $\mu \mathrm{m}$ thick. In SEM rugulose to wrinkled. Spores globose, subglobose, sometimes broadly ellipsoidal, (15.5-)16.5-20.5(-21.5) x (14.5-)15.5-19.5(-20.5) (18.7 $\pm 1.2 \times 18.2 \pm 1.2) \mu \mathrm{m}(\mathrm{n}=100)$, dark reddish brown; spore wall indistinctly two-layered, moderately verruculose to verrucose, $(1.6-) 1.8-2.5(-2.8) \mu \mathrm{m}$ thick (including the $0.4-1.0$ $\mu \mathrm{m}$ high ornamentation and hardly visible $0.5-0.9 \mu \mathrm{m}$ thick inner layer); usually covered by thin hyaline sheath. In SEM, warts densely spaced, often confluent in small groups or short rows.

Specimen examined - On Oplismenus burmannii (Retz.) P. Beauv.: SENEGAL, ZIGUINCHOR REGION, Basse Casamance (Lower Casamance), Djibonker, 5 m, 22 Oct 1988, leg. C. Vanden Berghen, no. 8599 (BR 0000015694461).

Distribution - On Poaceae: Oplismenus burmannii, O. compositus (L.) P. Beauv. (incl. O. setarius (Lam.) Roem. \& Schult.), O. hirtellus (L.) P. Beauv., O. undulatifolius (Ard.) P. Beauv.; South \& SE Asia, North \& Central America, Africa (Senegal, Guinea, Ethiopia, Uganda), and Australia (Mundkur 1941; Durán \& Fischer 1961; Durán 1987; Piepenbring 2003; Vánky 2011; Vánky et al. 2011).

Tilletia vittata is reported here for the first time from Senegal.

Although Tilletia vittata and T. oplismeni-cristati are similar in the way they convert the infected ovaries into more or less elongated, often curved bodies, covered by a hispid pericarp, they can easily be differentiated by their spore wall ornamentation.

Tilletia perotidis Thirum. \& Pavgi, Sydowia 6: 392, 1952. - Holotype on Perotis indica (L.) Kuntze, India, Bihar, Patna, 21 Oct 1951, leg. M.J. Thirumalachar \& M.S. Pavgi, s.n. (HCIO 20122).

Figs 14-19

Sori in all ovaries of infected plant, inconspicuous, concealed by glumes, fusiform, 0.6$0.9 \times 0.15-0.3 \mathrm{~mm}$, with a short, acute tip, bearing rudimentary style and stigmas, covered by a thin, greenish to yellowish brown pericarp that later ruptures exposing a powdery, dark reddish brown mass of spores and sterile cells. Sterile cells irregular, subglobose or broadly ellipsoidal, smaller than spores, $(8-) 10-15(-16) \times(7-) 9-14(-15)(13.2 \pm 1.6 \times$ $12.1 \pm 1.5) \mu \mathrm{m}(\mathrm{n}=50)$, hyaline; cell wall 1.2-3.0(-3.3) $\mu \mathrm{m}$ thick. In SEM, wall rugulose to wrinkled. Spores subglobose, broadly ellipsoidal or globose, (23.5-)24.5-29(-30) $\times$ $(22-) 23-26(-27.5)(26.4 \pm 1.2 \times 24.4 \pm 1.1) \mu \mathrm{m}(\mathrm{n}=100)$, medium reddish brown; spore wall (3.7-)4-5(-5.3) $\mu \mathrm{m}$ thick (including ornamentation, composed of 1.7-3.5(-3.8) $\mu \mathrm{m}$ high subconical ornaments); ornaments 17-24 on equatorial circumference, 5-7 per spore diameter, (0.6-)0.8-1.6(-2.0) $\mu \mathrm{m}$ high; hyaline sheath not seen. In SEM, ornaments usually not confluent, interconnected by thin ribs. 


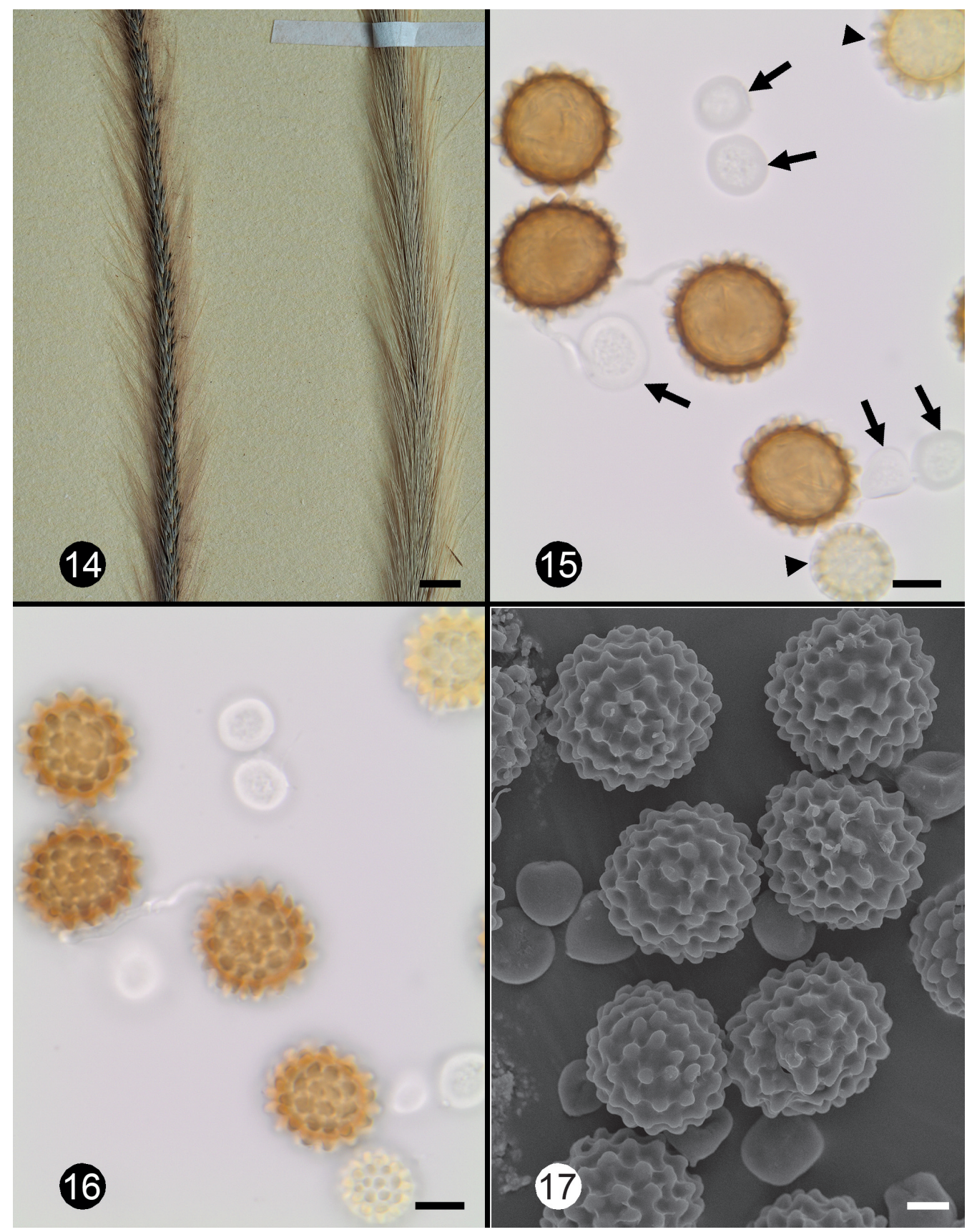

Figs 14-17. Tilletia perotidis on Perotis patens (P-P01929966). 14. An infected inflorescence (left) and a healthy inflorescence (right). 15, 16. Spores and sterile cells in LM (in median and surface view, respectively). In Fig. 15, arrows indicate sterile cells, arrowheads show immature spores. 17. Spores and sterile cells in SEM. Scale bars: $14=0.5 \mathrm{~cm}, 15,16$ $=10 \mu \mathrm{m}, 17=5 \mu \mathrm{m}$ 

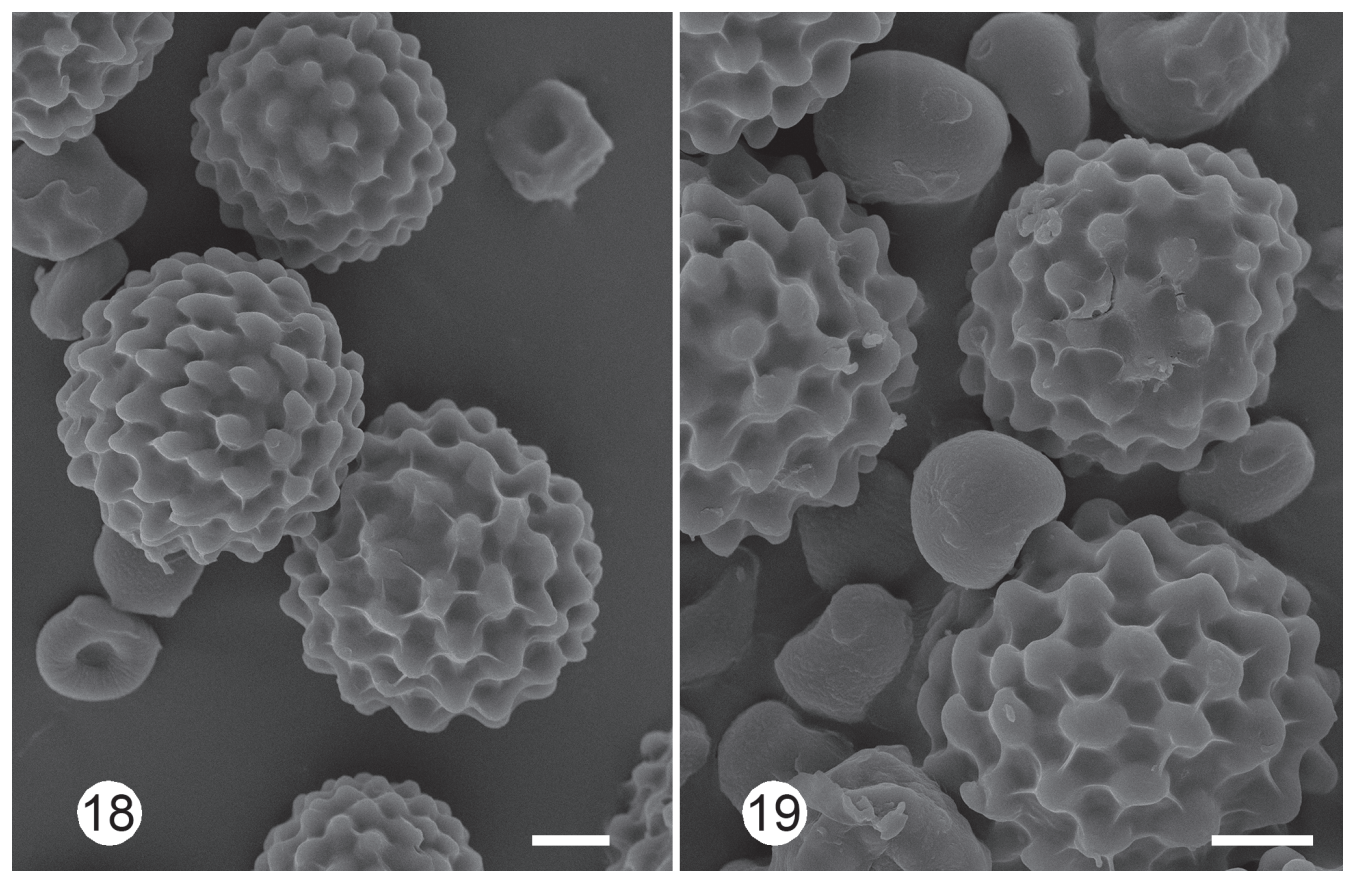

Figs 18, 19. Tilletia perotidis on Perotis patens (P-P01929966) - spores and sterile cells in SEM. Scale bars $=5 \mu \mathrm{m}$

Specimen examined - On Perotis patens Gand.: MADAGASCAR, MENABE

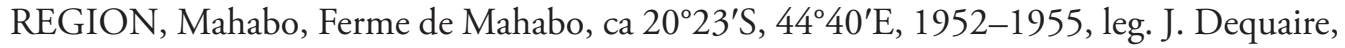
no. 27162 (P-P01929966, as 'Perotis latifolia Aiton', q.e. P. indica (L.) Kuntze).

Distribution - On Poaceae: Perotis indica, P. patens; South Asia (India), Africa (Malawi, Madagascar) (Thirumalachar \& Pavgi 1952; Vánky 2011; Vánky et al. 2011).

It is worth noting that in the examined specimen of $T$. perotidis all ovaries are infected while in the protologue (Thirumalachar \& Pavgi 1952: 392, and Fig. 9) and descriptions in Durán \& Fischer (1961) and Vánky (2011), the infection is given as restricted only to some ovaries.

Perotis (Poaceae: Chloridoideae) is a small genus (16 species) in the tribe Cynodonteae, subtribe Perotidinae (Soreng et al. 2017). Perotis patens is endemic to Africa, distributed in Tropical and South Africa and Madagascar (Klaassen \& Craven 2003). On this host, Tilletia perotidis has been previously recorded only from Malawi (Vánky et al. 2011). This smut fungus is reported here for the first time from Madagascar.

Acknowledgements. This research received support from the SYNTHESYS Plus project (https:/www.synthesys.info/), financed by the H2020 Research Infrastructures Programme at the Botanic Garden Meise, Belgium (Grant no. BE-TAF-2445), and from the SYNTHESYS 
Project (https://www.synthesys.info/), financed by European Community Research Infrastructure Action under the FP7 "Capacities" Program at the National Museum of Natural History, Paris (Grant no. FR-TAF-6628). The assistance of the staff of BR, Dr André Fraiture (Botanic Garden Meise), and Dr Thomas Haevermans (NMNH, Paris) is kindly acknowledged.

\section{References}

Bao, X.-D., Carris, L.M., Huang, G.-M., Luo, J.-F., Liu, Y.-T. \& Castlebury, L.A. 2010. Tilletia puccinelliae, a new species of reticulate-spored bunt fungus infecting Puccinellia distans. - Mycologia 102: 613-623. https://doi.org/10.3852/09-135

Denchev, C.M. \& Denchev, T.T. 2013. Erratomycetaceae, fam. nov., and validation of some names of smut fungi recently described from India. - Mycobiota 1: 63-70. https://doi.org/10.12664/ mycobiota.2013.01.07

Denchev, T.T. \& Denchev, C.M. 2018a. Two new smut fungi on Ventenata (Poaceae): Tilletia elizabethae from Slovakia and T. ventenatae from Turkey. - Willdenowia 48: 177-183. https://doi.org/10.3372/ wi.48.48201

Denchev, T.T. \& Denchev, C.M. 2018b. Tilletia tripogonellae (Tilletiaceae), a new smut fungus on Tripogonella spicata (Poaceae) from Argentina. - Annales Botanici Fennici 55: 273-277. https://doi. org/10.5735/085.055.0407

Denchev, T.T., van der Zon, A.P.M. \& Denchev, C.M. 2018. Tilletia triraphidis (Tilletiaceae), a new smut fungus on Triraphis purpurea (Poaceae) from Namibia. - Phytotaxa 375: 182-186. https://doi. org/10.11646/phytotaxa.375.2.5

Durán, R. 1987. Ustilaginales of Mexico. Taxonomy, symptomatology, spore germination, and basidial cytology. Washington State University Press, Pullman, Washington.

Durán, R. \& Fischer, G.W. 1961. The genus Tilletia. Washington State University Press, Pullman, Washington.

Klaassen, E.S. \& Craven, P. 2003. Checklist of grasses in Namibia. - In: M. Mössmer (ed.). Southern African Botanical Diversity Network Report. No. 20. Pp. 1-129. SABONET, Pretoria \& Windhoek.

Li, Y.-M., Shivas, R.G. \& Cai, L. 2014. Three new species of Tilletia on Eriachne from north-western Australia. - Mycoscience 55: 361-366. https://doi.org/10.1016/j.myc.2013.12.003

Mundkur, B.B. 1941. A second contribution towards a knowledge of Indian Ustilaginales. Fragments 26-50. - Transactions of the British Mycological Society 24[1940]: 312-336. https://doi.org/10.1016/ S0007-1536(40)80031-4

Piepenbring, M. 2003. Smut fungi (Ustilaginomycetes p.p. and Microbotryales, Basidiomycota). - Flora Neotropica 86: 1-291.

Soreng, R.J., Peterson, P.M., Romaschenko, K., Davidse, G., Teisher, J.K., Clark, L.G., Barberá, P., Gillespie, L.J. \& Zuloaga, F.O. 2017. A worldwide phylogenetic classification of the Poaceae (Gramineae) II: An update and a comparison of two 2015 classifications. - Journal of Systematics and Evolution 55: 259-290. https://doi.org/10.1111/jse.12262

Thiers, B. 2020+ [continuously updated]. Index Herbariorum: a global directory of public herbaria and associated staff. New York Botanical Garden's virtual herbarium. - Available from: http://sweetgum. nybg.org/science/ih/ (accessed 30 March 2020). 
Thirumalachar, M.J. \& Pavgi, M.S. 1952. Notes on some Indian Ustilagineae - 5. - Sydowia 6: 389-395 + Pls IV-V.

Vánky, K. 2004. Taxonomic studies on Ustilaginomycetes - 24. - Mycotaxon 89: 55-118.

Vánky, K. 2011['2012']. Smut fungi of the world. APS Press, St. Paul, Minnesota.

Vánky, K. 2013. Illustrated genera of smut fungi. $3^{\text {rd }}$ edn. APS Press, St. Paul, Minnesota.

Vánky, K., Vánky, C. \& Denchev, C.M. 2011. Smut fungi in Africa - a checklist. - Mycologia Balcanica 8: 1-77. https://doi.org/10.5281/zenodo.2550336 